Article

\title{
Age-Related Differences in Body Fatness and Nutritional Status in Large Sample of Serbian Women 20-70 Years of Age
}

\author{
Milivoj Dopsaj ${ }^{1,2} \oplus$, Filip Kukić ${ }^{3, *}\left(\mathbb{D}\right.$, Miloš Maksimović ${ }^{4}$, Boris Glavač ${ }^{5}$, Dragan Radovanović ${ }^{6}$ \\ and Marina Đorđević-Nikić ${ }^{1}$ \\ 1 Faculty of Sport and Physical Education, University of Belgrade, 11030 Belgrade, Serbia; \\ milivoj.dopsaj@gmail.com (M.D.); marinanikicmail@gmail.com (M.Đ.-N.) \\ 2 Institute of Sport, Tourism and Service, South Ural State University, 454080 Chelyabinsk, Russia \\ 3 Police Sports Education Center, Abu Dhabi, United Arab Emirates \\ 4 Faculty of Medicine, Institute of Hygiene and Medical Ecology, University of Belgrade, 11030 Belgrade, \\ Serbia; milosmaksimovic71@gmail.com \\ 5 Laboratory of Physical Education, Military Academy University of Defense, 11030 Belgrade, Serbia; \\ risbo@vektro.net \\ 6 Faculty of Sport and Physical Education, University of Niš, 18000 Niš, Serbia; drananiste@yahoo.com \\ * Correspondence: filip.kukic@gmail.com; Tel.: +971-56-4805956
}

\section{check for}

updates

Citation: Dopsaj, M.; Kukić, F.; Maksimović, M.; Glavač, B.;

Radovanović, D.; Đorđević-Nikić, M. Age-Related Differences in Body Fatness and Nutritional Status in Large Sample of Serbian Women 20-70 Years of Age. Obesities 2021, 1, 157-166. https://doi.org/10.3390/ Obesities1030014

Academic Editor:

Nobuyuki Takahashi

Received: 28 October 2021

Accepted: 12 November 2021

Published: 16 November 2021

Publisher's Note: MDPI stays neutral with regard to jurisdictional claims in published maps and institutional affiliations.

Copyright: (c) 2021 by the authors. Licensee MDPI, Basel, Switzerland. This article is an open access article distributed under the terms and conditions of the Creative Commons Attribution (CC BY) license (https:// creativecommons.org/licenses/by/ $4.0 /)$.
Abstract: Obesity due to increased body fatness has been recognized internationally as one of the leading factors affecting individual and public health. The aim of this study was to determine agerelated differences in body fatness in a representative sample of women in Serbia. The study included 1937 Serbian females aged 20 to 69.9 years from all regions of the Republic of Serbia. The obesity and body fatness were analyzed using body mass index (BMI), body fat mass (BFM), percent of body fat (PBF), body fat mass index (BFMI), and visceral fat area (VFA). Multivariate analysis of variance with post hoc pairwise comparisons revealed the largest differences between the age categories in VFA followed by BFMI, PBF, and BMI. The prevalence of overweight, obese, and extremely obese subjects in the overall sample by BMI was $30.77,1.32$, and $1.40 \%$, respectively. The prevalence was higher when calculated by PBF, with 37.84 and $20.11 \%$ for overweight and obese subjects. The prevalence of overweight and obesity, as calculated by BMI and PBF, was higher in older age groups of Serbian women. The prevalence of overweight women in the oldest group was 4.32 times higher, while the rate of obesity was 8.67 times higher than in the youngest group. Our results are a good basis for planning and implementing preventive health activities and monitoring changes in morphological parameters in Serbian women of different ages.

Keywords: morphology; body composition; bioimpedance; female; aging

\section{Introduction}

It is well known that deviation from normal body weight and excessive body fat content are associated with the most common chronic non-communicable diseases [1-3]. These diseases represent the biggest public health problem in developed and developing countries [4-8]. As early as 1985, it was proven that $60 \%$ of US African American women between the ages of 45-55 are obese, relative to 30\% of similar US white women and $26 \%$ of the entire US population and $35.63 \%$ and $36.50 \%$ for adult males and females, respectively [5]. Considering different jobs, the highest obesity prevalence had been found in motor vehicle operators i.e., $31.7 \%$ and $31.0 \%$ in man and woman, respectively [4]. One of the latest U.S. obesity rates results, showed significant increase over the period of time 1986 to 2002 , irrespective of race and gender with average yearly change from $0.61 \%( \pm 0.04)$ during the period from 1986 to 1995 and 0.95\% $( \pm 0.11)$ during the period from 1997 to 2002 [5].

For the Greece student population, results showed that $48.6 \%$ of them had increased central fat adiposity. The proportion of subjects with at least one metabolic risk factor 
present was $60.4 \%$. It was established that females with undesirable adiposity had a tendency for the gynecoid type of obesity. In contrast, the Greece results suggest that central body fat distribution in young women may reflect increased risk due to high visceral fat area (VFA) and particularly intra-abdominal fat levels [9].

In relation to the molecular base, it was determined that obesity is a consequence of a multidimensional problem that contains three mechanisms: feeding control, control of energy efficiency, and adipogenesis [10]. Changing lifestyle patterns to sedentary instead to more active leisure pursuits and to eating nutrient-poor instead of nutrient-rich food, results in positive energy balance that usually lead to an increase in the prevalence of overweight or obesity. Consequently, this leads to increase in cardiovascular or metabolic disease risk factors, regardless in all ages and both sexes [3,5,6,11].

Body structure-composition implies the set of substances the human organism is made of. From the biological aspect, in relation to the macro level, human organism is composed of four main measurable components, fluid (water), fat component, solid component (mineral substances such as bones), and protein (muscle component) [12,13]. In addition, body composition indices can determine the ratio between certain components or even segmentary ratio of the same components. That way the levels and proportion(s) of certain elements or segments can be determined more precisely which can be important in research or clinical work $[9,12,14-16]$.

According to indicators of the Institute of Public Health, adult population in Serbia is among the world top ranked in the number of diseased and deaths from heart and blood vessels diseases, metabolic and malignant diseases and others [6]. Although the concern about obesity among Serbian adults is growing, except to certain research conducted with the students and the working population $[11,17,18]$, no national cross-selection study has been conducted on a representative sample of women. This could be done using the method of multisegmental electrical bioimpedance for the purpose of defining the model of the body composition, i.e., for defining preliminary reference values and age-related trends among Serbian women [14]. Information on the women's body composition status is of crucial scientific and national importance, especially given the fact that Serbia is experiencing a rapid aging of the population, as well significant increase in obesity of $17.3 \%$ from 2000 to 2006 to $21.2 \%$ from 2006 to 2013 [19]. Monitoring changes in body composition in different age groups is important epidemiological, scientific, and strategical process, but it is also important for the control of the current status of public health at observed particular population $[2,15,20-22]$.

In relation to the strategy of prevention of public health, it is very important to define a monitoring system with models of the body composition of a population, or some part of it $[17,20,23-25]$. The foundation of deterministic technology of control and monitoring of the phenomenology of changes could provide standards for monitoring system that would provide relevant information for making strategic decisions in the public health system. Therefore, the aim of this study was to define a descriptive model of the body composition of population of women in Serbia. The practical purpose of the study was to analyze body composition using standard morphological variables (BH, BM, BMI, FFM, BFM, PBF, VFA) but also and some indexes (FFMI, BFMI) using DSM-BIA technology of measurement. Additionally, the initial age-specific percentile standards for the subject sample population will be calculated. In this way, valid scientific and health-care practical information will be provided, which will, of course, serve as a standard for future research of the examined area.

\section{Materials and Methods}

\subsection{Subjects and Study Design}

The research was realized as a non-experimental, cross-sectional study. Respondents who participated in the study were recruited using a combined technique of personal and public information. The sample included 1937 healthy Serbian females aged 20 to 69.9 years, and with averaged $\mathrm{BH}-167.5 \pm 6.8 \mathrm{~cm}$, and $\mathrm{BM}-67.5 \pm 14.4 \mathrm{~kg}$. The structure 
of participants in the study was: university students $(17.38 \%)$, women who worked in the police or army $(11.65 \%)$, working women employed in industry $(19.17 \%)$, women employed in administration $(32.76 \%)$, women employed in university and health $(8.72 \%)$, as well as women employed in trade and other service activities (10.32\%). The sample was recruited from central $(36.5 \%)$, sauterne $(17.9 \%)$, and north $(15.6 \%)$ part of Serbia, as well as from the capital city of Belgrade (30.0\%). The average age of the sample was $35.7 \pm 11.6$ years, those who reported working status had on average $14.1 \pm 10.3$ years of service. All subjects were fully informed about aim of the study and they were administered to the assessment only after they consented to take part. Competitive athletes and subjects with medical diagnosis of motor skill or metabolic disorder were not assessed for this study. Subjects were allocated into five age groups: $20-29$ years $(n=885), 30-39$ years $(n=450), 40-49$ years $(n=276), 50-59$ years $(n=215)$, and $60-69$ years $(n=111)$.

\subsection{Body Composition}

Body composition was assessed using multisegmental bioelectrical impedance analyzer with tetrapolar 8-point tactile electrode system (In Body 720, Biospace, Co., Ltd.; Seoul, Korea). This is a non-invasive, easy-to-use, reproducible, and less expensive method for measuring and estimating body composition, widely used in laboratory and field settings $[13,20,21]$. InBody 720 was shown to be valid, reliable and sensitive elsewhere $[17,20,22]$. The same official InBody service provider (Borf d.o.o, Belgrade, Serbia) calibrated all machines twice a year (once each six months). All subjects were measured according to the previously procedures reported $[14,15,20,26]$.

All measurements were performed in the period October 2014-April 2019 in the teaching-research laboratory of the Faculty of Sport and Physical Education, University of Belgrade, Laboratory of the Faculty of Sport and Physical Education, University of Niš, laboratory in Institute of Hygiene and Medical Ecology, Faculty of Medicine, University of Belgrade, and in Laboratory of Physical Education, Military Academy, Belgrade, Serbia. The procedures were standardized across laboratories and all testers followed the same step-bystep written procedure. Measurements were realized in the morning hours (between 8:00 and 11:00 am) and subjects were asked not to consume a heavy meal the day prior to the assessment. Subjects were also advised not have any vigorous physical exercise within the $48 \mathrm{~h}$ before the assessment. On the day assessment, they neither had breakfast nor drank anything before the assessment and they were asked to empty the bladder if they could. No subject was measured during the menstrual period. Measurements were performed either in light sports equipment (shorts and T-shirts) or in underwear. Subjects removed all metal objects (e.g., rings, chains, earrings, watches, piercings, hair clips, etc.). Subjects with any recorded and known health edema, with a metal object in the body, or pregnant women were not measured. The room temperature during the measuring was between 22 and 25 degrees, in accordance with the manufacturer's recommendations. During the study period, all InBody720 devices were maintained in accordance with the technical instructions of the manufacturer, and the calibration was performed at a six-month level by the company of an authorized national representative (http:/ /www.inbody.rs/, accessed on 10 October 2021).

\subsection{Variables}

For the purposes of this study, the following variables were used to describe the body composition of the examined sample of women [12,16,17,21]:

1. Body mass index $(\mathrm{BMI})$, calculated as: $\mathrm{BMI}=\mathrm{BM}(\mathrm{kg}) / \mathrm{BH}\left(\mathrm{m}^{2}\right)$, expressed in $\mathrm{kg} / \mathrm{m}^{2}$;

2. Body fat mass (BFM), expressed in $\mathrm{kg}$;

3. Percent of body fat $(\mathrm{PBF})$, calculated as: $\mathrm{PBF}=\mathrm{BF} / \mathrm{BM}$, expressed in $\%$;

4. Body fat mass index $(\mathrm{BFMI})$, calculated as: $\mathrm{BFMI}=\mathrm{BFM}(\mathrm{kg}) / \mathrm{BH}\left(\mathrm{m}^{2}\right)$, expressed in $\mathrm{kg} / \mathrm{m}^{2}$;

5. VFA, visceral fat area, expressed in $\mathrm{cm}^{2}$. 


\subsection{Statistical Analyses}

Descriptive statistical parameters were calculated for central tendency and dispersion of data (Mean $\pm \mathrm{SD}$ ). For calculation of specific distribution standards, age-specific percentile classes were defined for the following percentiles: 2.5th, 5th, 10th, 25th, 50th, 75th, 90th, 95th, and 97.5th. Multivariate analysis of variance (MANOVA) was used to investigate the difference in body composition between the age groups. Wilks' lambda indicates general differences between groups in relation to the size of the effect, while Bonferroni post hoc analysis calculated differences between the individual age groups. The level of difference of measurements between individual variables was determined on the probability level of $95 \%$, i.e., $p$ value of 0.05 [27]. The prevalence of overweight and obese subjects was calculated by BMI and PBF criteria. Software SPSS Statistics 23.0 and R stats version 4.1.0 were used for all statistical analyses.

\section{Results}

Table 1 shows the descriptive statistics for investigated variables in a function of the examined age groups and for the whole sample.

Table 1. Descriptive statistics of all variables in a function of the examined age groups.

\begin{tabular}{ccccccc}
\hline Variables & $\begin{array}{c}\mathbf{2 0 - 2 9} \text { Years } \\
(\boldsymbol{n}=\mathbf{8 8 5})\end{array}$ & $\begin{array}{c}\text { 30-39 Years } \\
(\boldsymbol{n}=\mathbf{4 5 0})\end{array}$ & $\begin{array}{c}\mathbf{4 0 - 4 9} \text { Years } \\
(\boldsymbol{n}=\mathbf{2 7 6})\end{array}$ & $\begin{array}{c}\mathbf{5 0 - 5 9} \text { Years } \\
(\boldsymbol{n}=\mathbf{2 1 5})\end{array}$ & $\begin{array}{c}\text { 60-69 Years } \\
(\boldsymbol{n}=\mathbf{1 1 1})\end{array}$ & $\begin{array}{c}\text { Whole Sample } \\
(\boldsymbol{n}=\mathbf{1 9 3 7})\end{array}$ \\
\cline { 2 - 7 } & Mean \pm SD & Mean \pm SD & Mean \pm SD & Mean \pm SD & Mean \pm SD & Mean \pm SD \\
\hline Age (years) & $23.4 \pm 2.6$ & $34.0 .9 \pm 2.9$ & $44.6 \pm 2.9$ & $54.4 \pm 2.8$ & $63.9 \pm 3.2$ & $34.6 \pm 12.1$ \\
BH (cm) & $168.3 \pm 6.6$ & $169.2 \pm 6.5$ & $167.5 \pm 6.4$ & $164.3 \pm 6.2$ & $161.1 \pm 5.8$ & $166.1 \pm 6.3$ \\
BM (kg) & $62.6 \pm 11.2$ & $67.9 \pm 13.5$ & $73.3 \pm 16.2$ & $73.5 \pm 14.1$ & $78.9 \pm 19.4$ & $71.2 \pm 14.9$ \\
BMI (kg m $\left.{ }^{-2}\right)$ & $22.12 \pm 3.65$ & $23.75 \pm 4.77$ & $26.11 \pm 5.57$ & $27.24 \pm 5.03$ & $30.33 \pm 6.79$ & $24.11 \pm 5.19$ \\
BFM (kg) & $16.46 \pm 8.10$ & $19.70 \pm 10.58$ & $24.97 \pm 11.93$ & $27.91 \pm 10.74$ & $33.09 \pm 13.03$ & $20.65 \pm 11.15$ \\
BFMI (kg) & $5.84 \pm 2.89$ & $6.94 \pm 3.85$ & $8.95 \pm 4.29$ & $10.37 \pm 3.97$ & $12.72 \pm 4.87$ & $7.44 \pm 4.13$ \\
PBF (\%) & $25.17 \pm 7.78$ & $26.96 \pm 9.49$ & $32.16 \pm 9.00$ & $36.40 \pm 8.11$ & $40.04 \pm 7.35$ & $28.68 \pm 9.61$ \\
VFA (cm $\left.{ }^{2}\right)$ & $51.2 \pm 31.8$ & $76.0 \pm 40.1$ & $106.5 \pm 43.9$ & $128.9 \pm 40.8$ & $160.7 \pm 42.9$ & $79.1 \pm 50.2$ \\
\hline
\end{tabular}

Table 2 shows the results of MANOVA and ANOVA. It was found that the examined age groups are generally statistically significantly different at the level of Wilks' Lambda Value-0.174, $p<0.001$, Partial $\mathrm{Eta}^{2}=0.354$. The results of ANOVA showed significant difference between the age groups in all variables. The highest effect could be observed in VFA followed by BFMI, PBF, and BMI. Figure 1 shows the pairwise comparisons between the age groups in BMI, BFM, BFMI, PBF, and VFA. Each consecutive older group had significantly higher body fatness than the previous age groups.

Table 2. General and partial differences between age groups in investigated variables.

\begin{tabular}{cccccccc}
\hline $\begin{array}{c}\text { Dependent } \\
\text { Variable }\end{array}$ & $\begin{array}{c}\text { Type III Sum of } \\
\text { Squares }\end{array}$ & Df. & Mean Square & F & Sig. & Partial Eta $^{2}$ & Observed Power $^{\text {Ond }}$ \\
\hline BMI $\left(\mathrm{kg} \mathrm{m}^{-2}\right)$ & 9414.0 & 4 & 2353.5 & 116.87 & 0.000 & 0.219 & 1.00 \\
BFM $\left(\mathrm{kg}^{2}\right)$ & $426,21.4$ & 4 & 10655.4 & 113.35 & 0.000 & 0.214 & 1.00 \\
BFMI $\left(\mathrm{kg} \mathrm{m}^{-2}\right)$ & 6646.4 & 4 & 1661.6 & 136.31 & 0.000 & 0.247 & 1.00 \\
PBF $(\%)$ & $34,650.7$ & 4 & 8662.7 & 126.86 & 0.000 & 0.234 & 1.00 \\
VFA $\left(\mathrm{cm}^{2}\right)$ & $18,8750.3$ & 4 & 47193.6 & 402.61 & 0.000 & 0.492 & 1.00 \\
\hline
\end{tabular}



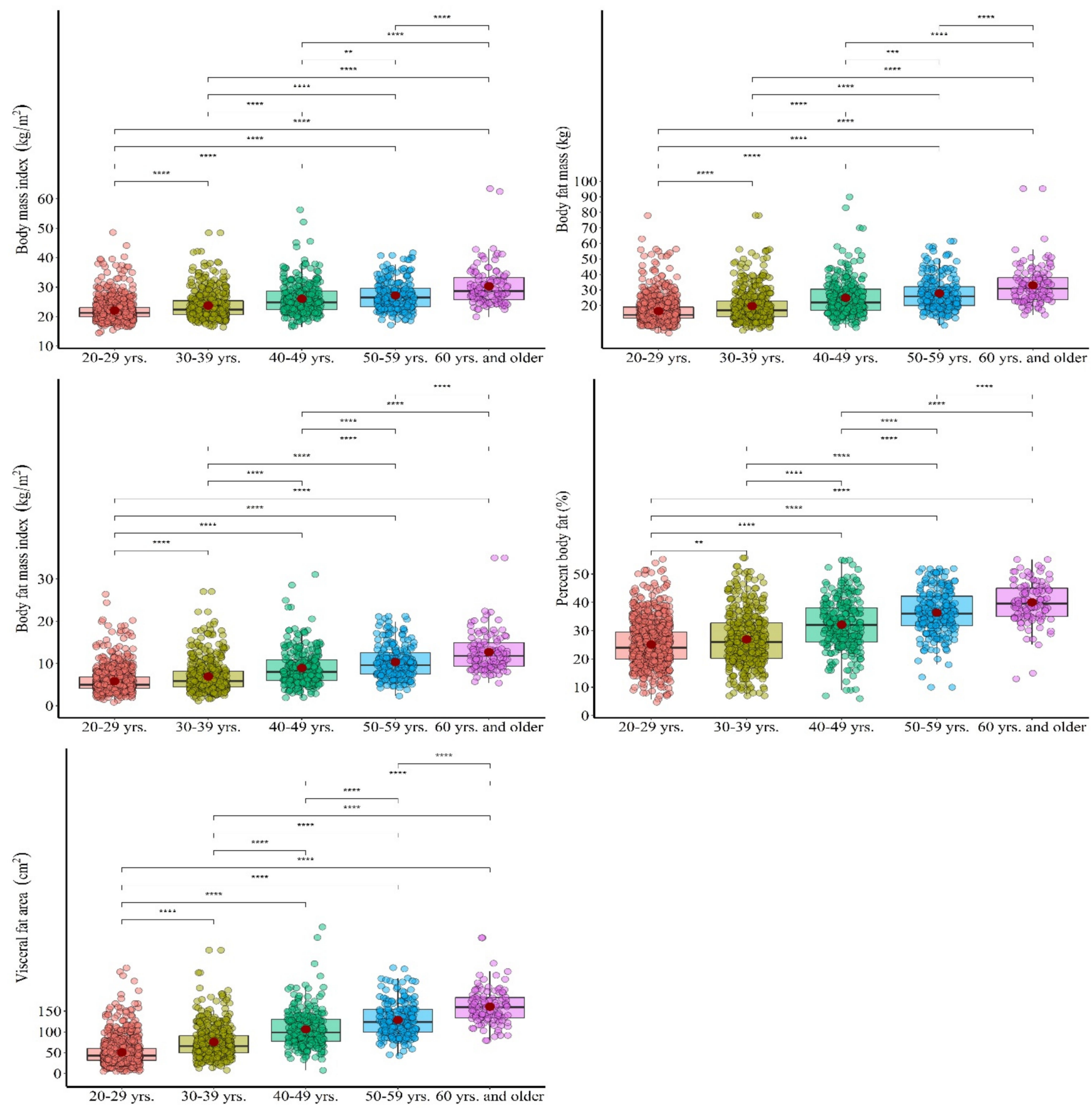

Figure 1. Pairwise comparisons for BMI, BFM, BFMI, PBF, and VFA. Note: ${ }^{* *}$ Significant at $p<0.01,{ }^{* *}$ Significant at $p<0.001,{ }^{* * * *}$ Significant at $p<0.0001$.

Table 3 shows the results of the percentile distribution of all variables in a function of the examined age groups. Table 4 shows the prevalence of overweight and obesity in relation to two criteria: BMI $\left(\mathrm{kg} / \mathrm{m}^{2}\right)$ and PBF $(\%)$. It was found that the prevalence for overweight and obesity increases proportionally with age, and that the total prevalence is at the level of $30.77 \%$ for overweight, $12.32 \%$ for obese, and $1.40 \%$ for extreme obese for BMI, and $37.84 \%$ for overweight and $20.11 \%$ for obese for PBF criterion. 
Table 3. Results of the percentile distribution of variables in a function of the age groups.

\begin{tabular}{|c|c|c|c|c|c|c|c|c|c|c|}
\hline & Percentiles & 2.5 & 5.0 & 10.0 & 25.0 & 50.0 & 75.0 & 90.0 & 95.0 & 97.5 \\
\hline \multirow{5}{*}{$\begin{array}{c}\text { BMI } \\
\left(\mathrm{kgm}^{-2}\right)\end{array}$} & 20-29 years & 17.63 & 18.35 & 18.90 & 19.96 & 21.26 & 23.09 & 26.09 & 28.94 & 32.79 \\
\hline & $30-39$ years & 18.25 & 18.90 & 19.45 & 20.66 & 22.44 & 25.48 & 30.50 & 33.60 & 37.05 \\
\hline & 40-49 years & 18.41 & 19.47 & 20.82 & 22.29 & 24.84 & 28.71 & 32.89 & 36.51 & 38.23 \\
\hline & 50-59 years & 19.08 & 20.59 & 21.45 & 23.38 & 26.50 & 29.71 & 35.23 & 36.51 & 39.85 \\
\hline & 60-69 years & 22.49 & 23.31 & 24.10 & 25.63 & 28.69 & 33.45 & 39.12 & 41.34 & 46.97 \\
\hline \multirow{5}{*}{$\begin{array}{c}\text { BFM } \\
\text { (kg) }\end{array}$} & 20-29 years & 7.10 & 9.00 & 10.00 & 11.75 & 14.00 & 19.00 & 25.38 & 32.00 & 39.26 \\
\hline & 30-39 years & 8.00 & 9.00 & 10.00 & 12.98 & 17.00 & 23.00 & 33.94 & 40.45 & 50.00 \\
\hline & 40-49 years & 9.00 & 11.00 & 13.00 & 17.00 & 22.00 & 30.88 & 39.09 & 46.47 & 55.40 \\
\hline & 50-59 years & 12.94 & 14.00 & 16.00 & 20.00 & 26.00 & 32.60 & 44.00 & 50.64 & 56.14 \\
\hline & $60-69$ years & 16.00 & 17.66 & 21.04 & 23.80 & 31.00 & 38.00 & 47.16 & 51.62 & 69.46 \\
\hline \multirow{5}{*}{$\begin{array}{c}\text { BFMI } \\
\left(\mathrm{kgm}^{-2}\right)\end{array}$} & $20-29$ years & 2.66 & 3.04 & 3.44 & 4.09 & 5.00 & 6.83 & 9.19 & 11.29 & 14.03 \\
\hline & 30-39 years & 2.62 & 2.95 & 3.46 & 4.43 & 5.89 & 8.28 & 12.30 & 14.80 & 17.94 \\
\hline & 40-49 years & 3.29 & 3.79 & 4.90 & 5.99 & 8.00 & 10.87 & 14.39 & 17.19 & 18.43 \\
\hline & 50-59 years & 4.64 & 5.09 & 5.98 & 7.49 & 9.67 & 12.76 & 16.77 & 18.48 & 20.23 \\
\hline & 60-69 years & 6.49 & 7.36 & 8.17 & 9.35 & 11.80 & 15.13 & 18.00 & 20.83 & 24.93 \\
\hline \multirow{5}{*}{$\begin{array}{l}\text { PBF } \\
(\%)\end{array}$} & 20-29 years & 12.00 & 14.74 & 16.94 & 20.00 & 24.00 & 29.52 & 35.94 & 39.02 & 44.17 \\
\hline & 30-39 years & 9.67 & 12.89 & 16.00 & 20.35 & 25.97 & 32.68 & 40.96 & 45.01 & 48.81 \\
\hline & 40-49 years & 13.85 & 17.00 & 22.00 & 26.00 & 32.00 & 38.00 & 44.00 & 47.01 & 49.23 \\
\hline & 50-59 years & 19.58 & 23.22 & 26.90 & 31.77 & 36.00 & 42.34 & 47.20 & 50.49 & 50.95 \\
\hline & 60-69 years & 23.00 & 28.14 & 32.67 & 35.00 & 39.56 & 45.00 & 49.90 & 51.50 & 53.49 \\
\hline \multirow{5}{*}{$\begin{array}{l}\text { VFA } \\
\left(\mathrm{cm}^{2}\right)\end{array}$} & 20-29 years & 13.30 & 18.00 & 24.00 & 31.30 & 43.00 & 60.00 & 87.00 & 115.15 & 141.91 \\
\hline & 30-39 years & 25.01 & 28.70 & 38.91 & 50.00 & 66.50 & 91.75 & 126.91 & 153.87 & 183.80 \\
\hline & 40-49 years & 41.70 & 51.84 & 60.70 & 78.00 & 99.00 & 130.00 & 157.00 & 185.36 & 207.60 \\
\hline & 50-59 years & 67.29 & 75.26 & 84.00 & 99.00 & 124.00 & 153.80 & 184.10 & 213.36 & 224.39 \\
\hline & 60-69 years & 86.88 & 96.72 & 113.42 & 133.00 & 159.50 & 183.00 & 207.40 & 236.52 & 277.26 \\
\hline
\end{tabular}

Table 4. The results of the prevalence of overweight/obesity in relation to two criteria: BMI $\left(\mathrm{kg} / \mathrm{m}^{2}\right)$ and PBF (\%).

\begin{tabular}{cccccc}
\hline \multirow{2}{*}{ Variables } & \multicolumn{2}{c}{ Criteria: BMI $\mathbf{( k g / \mathbf { m } ^ { \mathbf { 2 } } ) \text { -Prevalence }}$} & \multicolumn{2}{c}{ * Criteria: PBF (\%)-Prevalence } \\
\cline { 2 - 6 } & $\begin{array}{c}\text { Overweight } \\
(<\mathbf{2 5 . 0 0 )}\end{array}$ & $\begin{array}{c}\text { Obesity } \\
(<\mathbf{3 0 . 0 0 )}\end{array}$ & $\begin{array}{c}\text { Extreme Obesity } \\
(\mathbf{< 4 0 . 0 0 )}\end{array}$ & $\begin{array}{c}\text { Overweight } \\
(<31.00)\end{array}$ & $\begin{array}{c}\text { Obesity } \\
\mathbf{( < 3 7 . 0 0 )}\end{array}$ \\
\hline 20-29 years & 13.71 & 3.89 & 0.34 & 21.26 & 8.00 \\
30-39 years & 27.01 & 10.94 & 1.12 & 27.46 & 15.18 \\
40-49 years & 46.74 & 19.57 & 1.81 & 52.90 & 28.62 \\
50-59 years & 62.62 & 24.77 & 2.34 & 76.17 & 43.46 \\
60-69 years & 79.28 & 42.34 & 8.11 & 91.89 & 69.37 \\
Whole sample & 30.77 & 12.32 & 1.40 & 37.84 & 20.11 \\
\hline
\end{tabular}

* PBF criteria was established according to: Jaukendrup \& Gleeson, 2009, Table 13.1. [28].

\section{Discussion}

\subsection{Body Height, Body Weight, and Body Mass Index}

The main body high of the whole sample was $167.5 \pm 6.8 \mathrm{~cm}$, and all observed age groups are significantly different at $\mathrm{F}=34.05, p=0.000$. ANOVA showed that the partial difference of $\mathrm{BH}$ between the groups explains $7.6 \%$ of the total difference of the examined body characteristics $\left(\eta^{2}=0.076\right)$. It was determined that $\mathrm{BH}$ in women from the first three age groups, i.e., from 20.0-29.9, 30.0-39.9 and 40.0-49.9 years do not differ from each other, as well as that the two oldest age groups, i.e., from 50.0-59.9 and 60.0-69.9 years do not differ, but the given two sets of groups differ statistically significantly from each other $(p=0.001)$. Based on the obtained results, it can be concluded that women are only from the 5 th decade, i.e., from 50 years of age statistically significantly lower than women aged up to 50 years.

In relation to the results of research by authors from other countries, it can be argued that the sample of women from Serbia was higher than Greek women $(160.1 \pm 6.2 \mathrm{~cm})$ [29], 
Swiss women $(163.3 \pm 6.8 \mathrm{~cm})$ [12], and the Czechs $(164.7 \pm 7.2 \mathrm{~cm})$ [21], i.e., that it is higher than the average height of women in Europe-163.5 $\pm 7.2 \mathrm{~cm}$ [7], but similar to the Swedish woman $(167.3 \pm 6.6 \mathrm{~cm})$ [30]. Serbia belongs to the Western Balkans region (the area of the Dinaric Alps) for which it was determined that the given population of men belongs to $15 \%$ of the tallest nations in Europe [31]. It could be assumed that the determined body height of Serbian women from of this sample belongs to the category above the average body height of women in Europe.

The average weight of the whole sample was $67.5 \pm 14.4 \mathrm{~kg}$, and all observed age groups are significantly different at $\mathrm{F}=66.18, p=0.000$. ANOVA showed that for BM eta ${ }^{2}$ $\left(\eta^{2}\right)$ was at the level of $13.7 \%$. BM was found to differ statistically significantly between all age groups except the 40.0-49.9 and 50.0-59.9 age groups (Table 1). Based on the given results, it can be concluded that in women from the examined sample the process of weight gain was constant from 20 to 40 years, that between 40 and 59 years their BM maintained the same level, and that after 60 the trend of increase BM the most intense continues (average increase in BM between the first three groups was $3.60 \mathrm{~kg}$, while the increase in $\mathrm{BM}$ in the oldest group was as much as $8.8 \mathrm{~kg}$ ).

In relation to the previously published results, it can be argued that the sample of women from Serbia in relation to BM weighs more than Greek women-62.8 $\pm 7.4 \mathrm{~kg}$ [29], than Swiss women-60.0 $\pm 8.7 \mathrm{~kg}$ [12], from the Czechs-65.5 $\pm 11.1 \mathrm{~kg}$ [21], i.e., that it is slightly higher than the average BM of women in Europe- $66.0 \pm 12.9 \mathrm{~kg}$ [7] and is almost the same as in Swedish woman-67.0 $\pm 13.1 \mathrm{~kg}$ to $68.7 \pm 12.1$ for 38 and 50 years old women, respectively [30]. It was found that the value of $\mathrm{BM}$ in relation to the basic level of age (20-29.9 yrs. Group) as a function older age groups increases by $8.47 \%, 17.09 \%, 17.41 \%$ and $26.04 \%$, respectively, where the given numerical values are based on the exponential form of BM increase.

In relation to BMI, the average value of the whole sample was $24.11 \pm 5.19\left(\mathrm{kgm}^{-2}\right)$, and according to the WHO standards it is in the upper limit of the normal range (23.00-24.99 additional cut-off points, [1]). However, the average BMI value of the subjects aged $40-49$ and $50-59$ yrs. belong to the category of overweight $\left(26.11 \pm 5.57\right.$ and $27.24 \pm 5.03 \mathrm{kgm}^{-2}$, respectively), while the average value of the oldest group of 60-69 yrs. even belongs to the group of obese $\left(30.33 \pm 6.79 \mathrm{kgm}^{-2}\right.$, Table 1$)$. All observed age groups are highly statistically significantly different at $F=116.87, p=0.000$ (Table 2). ANOVA showed that for BMI eta ${ }^{2}\left(\eta^{2}\right)$ was at the level of $21.9 \%$. It was found that all examined age groups differed from each other statistically significantly in relation to BMI (Table 1, Figure 1). In relation to the previously published research, it can be argued that BMI at the sample of Serbian women is lower than in Greek women $\left(24.58 \pm 3.80 \mathrm{kgm}^{-2}\right.$, [29]), very similar to in Czechs $\left(24.2 \pm 4.3 \mathrm{kgm}^{-2}\right.$, [21]), lower than the average BMI of women in Europe $\left(24.7 \pm 4.8 \mathrm{kgm}^{-2},[7]\right)$, higher than women from Switzerland (22.5 $\pm 3.3 \mathrm{kgm}^{-2}$, [12] $)$, and within the range of Swedish women $\left(23.9 \pm 4.3\right.$ to $24.8 \pm 4.3 \mathrm{kgm}^{-2}$ for 38 and 50 years old women, respectively [30]).

Additionally, for BMI it was determined that in relation to the basic level of age (20-29.9 yrs. group) in the function of older age groups changes occur towards an increase of $7.37 \%, 18.04 \%, 23.15 \%$ and $37.12 \%$, respectively, where the given increases numerically observed, as in the case of BM, they also have an exponential shape.

In relation to the prevalence of overweight, obesity, and extreme obesity in relation to the BMI criterion, the results showed that the overall was at the level of $30.77 \%, 12.32 \%$ and $1.40 \%$, respectively (Table 4 ). These results are very similar to the results of the given prevalence of women from Europe (prevalence-29.3\%, 11.5\% and 0.7\%, respectively), which places the sample of women from Serbia above average ranked compared to the European population, because the current sample has a higher prevalence of $5.02 \%, 7.13 \%$ and $100 \%$, i.e., double higher for the mentioned BMI categories [7]. 


\subsection{Body Fat Mass, Percent of Body Fat, and Body Fat Mass Index}

The mean values of the whole sample for BFM, \%BF and BFMI was $20.65 \pm 11.15 \mathrm{~kg}$, $28.68 \pm 9.61 \%$ and $7.44 \pm 4.13 \mathrm{kgm}^{-2}$, respectively (see Table 1 ). All observed age groups were significantly different between each other (see Figure 1). ANOVA showed that for BFM eta ${ }^{2}\left(\eta^{2}\right)$ was at the level of $21.4 \%$, for PBF was $23.4 \%$, and for BFMI was $24.7 \%$.

It was found that all age groups differ statistically significantly in relation to all three variables, i.e., BFM, PBM and BFMI (Table 1). These results practically determined that the sample of examined women during life constantly has statistically significant increase in all monitored components of adipose tissue, regarding in relation to the absolute and relative amount of fat, as well as in relation to the amount of fat standardized per transverse surface of the body $\left(\mathrm{BH}^{2}\right)$. Compared to the baseline age level (20.0-29.9 yrs. group) the value of BFM absolutely increases by $19.68,51.70,69.56$ and $101.03 \%$ by age, respectively, PBF absolutely increases by $7.11,27.77,44.62$ and $59.08 \%$ by age, respectively, while BFMI absolutely increased by $18.84,53.25,77.57$ and $117.81 \%$ by age, respectively. In relation to the given results, the largest peak of change towards fat increase occurs primarily between the age periods $30.0-39.9$ vs. $40.0-49.9$, while the next peak then occurs in the period $50.0-59.9$ vs. $60.0-69.9$ years.

It was found that women from Serbia have a BFM and BFMI higher than women from Switzerland in whom BFM is at the level of $17.6 \pm 6.1 \mathrm{~kg}$ and BFMI at $6.6 \pm 2.4 \mathrm{kgm}^{-2}$ [12], as well as in Czechs BFM of $19.7 \pm 8.9 \mathrm{~kg}$ and BFMI of $7.25 \mathrm{kgm}^{-2}$ [21]. However, the average value of PBF in the examined sample is lower than previously determined for women from the Czech Republic, $29.1 \pm 8.9 \%$, and the same with Swiss data, $28.7 \pm 6.4 \%$ [12,21]

The overall Serbian sample prevalence of overweight and obesity but relative to the PBF criterion was 37.84 and $20.11 \%$, respectively (Table 4 ). The lowest prevalence was found in the youngest group $(21.26 \%$ and $8.00 \%$, respectively), while the highest was found in the oldest group of respondents (91.89 and $69.37 \%$, respectively). The results of this study showed that the increase in the prevalence of overweight from the youngest to the oldest age of the examined women was 4.32 times higher, while in obesity it was higher by as much as 8.67 times (Table 4 ).

\subsection{Visceral Fat Area}

Considering abdominal fatness around the viscera, all observed age groups had significantly different VFA (see Table 2). The Eta ${ }^{2}$ was at the level of $49.2 \%$. The obtained results suggest significant increase of the abdominal fat tissue around the internal organs thus increasing the health risk [3]. Compared to the youngest age group (20.0-29.9 yrs. group) the VFA differed by $48.44,108.01,151.76$ and $213.87 \%$ in each consecutively older group.

\subsection{Limitations}

A few limitations should be mentioned. Although the sample size was large, future studies with longitudinal design should be conducted, especially considering that technological development allows a convenient, precise, and reliable assessment of body composition. Sub-sample sizes of older subjects could be larger (i.e., equal to younger subsamples). Variables such as the level of physical activity, nutritional habits, environmental and socio-cultural variables as well as education level should be assessed in the future to control for possible moderating effects.

\section{Conclusions}

Results showed that the greatest influence of an individual variable on the difference between groups was found in the variable VFA (49.4\%), BFMI (25.0\%), PBF, and BMI (23.8 and $22.1 \%$, respectively). The prevalence of overweight and obesity was calculated in relation to two criteria: BMI $\left(\mathrm{kgm}^{-2}\right)$ and PBF (\%), and it was found that the prevalence for overweight and obesity increases proportionally with age. The total prevalence is at the level of $30.77 \%$ for overweight, $12.32 \%$ for obese, and $1.40 \%$ for extreme obese for BMI, and 
$37.84 \%$ for overweight and $20.11 \%$ for obese considering PBF as a criterion. Additionally, the results of this study showed that the increase in the prevalence of overweight from the youngest to the oldest age of the examined women was 4.32 times higher, while in obesity it was higher by as much as 8.67 times. Comparing results of overweight and obesity prevalence from Serbia it can be concluded that the prevalence of the sample of women from Serbia are above average ranked compared to the European population.

Author Contributions: Conceptualization, M.D. and F.K.; methodology, M.D. and F.K.; validation, M.Đ.-N. and D.R.; formal analysis, M.D. and F.K.; investigation, M.D., M.M., B.G., D.R. and M.Đ.-N.; data curation, M.D., M.M., B.G., D.R. and M.Đ.-N.; writing—original draft preparation, M.D.; writing—review and editing, M.D., F.K. and M.Đ.-N.; supervision, M.M. and D.R.; project administration, M.D., M.M., B.G., D.R. and M.Đ.-N. All authors have read and agreed to the published version of the manuscript.

Funding: This study was not funded.

Institutional Review Board Statement: The study was conducted according to the guidelines of the Declaration of Helsinki, and approved by the Ethics Committee of the Faculty of Sport and Physical Education, University of Belgrade (number 484-2).

Informed Consent Statement: Informed consent was obtained from all subjects involved in the study.

Data Availability Statement: Data are available upon request on milivoj.dopsaj@fsfv.bg.ac.rs.

Acknowledgments: This study was a part of the program projects funded by the Ministry of Science and Technology Development of the Republic of Serbia (No. III47015, 2011-2021).

Conflicts of Interest: The authors declare no conflict of interest.

\section{References}

1. WHO. Consultation on obesity. In Obesity: Preventing and Managing the Global Epidemic; (WHO Technical Report Series); WHO: Geneva, Switzerland, 2000; Volume 894.

2. Adams, K.; Schatzkin, A.; Harris, T.; Kipnis, V.; Mouw, T.; Ballard-Barbash, R.; Hollenbeck, A.; Leitzmann, M. Overweight, obesity and mortality in a large prospective cohort of persons 50 to 71 years old. N. Engl. J. Med. 2006, 355, 763-778. [CrossRef] [PubMed]

3. De Lorenco, A.; Bianchi, A.; Maroni, P.; Iannarelli, A.; Di Daniele, N.; Iacopino, L.; De Renzo, L. Adiposity rather than BMI determines metabolic risk. Int. J. Cardiol. 2011, 66, 111-117. [CrossRef]

4. Caban, A.; Lee, D.; Fleming. L.; Gómez-Marin, O.; LeBlanc, W.; Pitman, T. Obesity in US workers: The national health interview survey, 1986 to 2002. Am. J. Public Health 2005, 95, 1614-1622. [CrossRef]

5. Ogden, C.; Carroll, M.; Kit, B.; Flegal, K. Prevalence of Obesity in the United States, 2009-2010 NCHS Data Brief, No. 82; National Center for Health Statistics: Hyattsville, MD, USA, 2012.

6. Boričić, K.; Vasić, M.; Grozdanov, J.; Gudelj-Rakić, J.; Živković-Šulović, M.; Jaćović-Knežević, N.; Jovanović, V.; Kilibarda, V.; Knežević, T.; Krstić, M.; et al. Rezultati Istraživanja Zdravlja Stanovništva Srbija-2013 Godina; Institut za Javno Zdravlje Srbije “Dr Milan Jovanović Batut": Belgrade, Serbia, 2014.

7. Gallus, S.; Lugo, A.; Murisic, B.; Bosetti, C.; Boffetta, P.; La Vecchia, C. Overweight and obesity in 16 European countries. Eur. J. Nutr. 2015, 54, 679-689. [CrossRef] [PubMed]

8. Rana, K.; Ghimire, P.; Chimoriya, R.; Chimoriya, R. Trends in the prevalence of overweight and obesity and associated socioeconomic and household environmental factors among women in Nepal: Findings from the Nepal demographic and health surveys. Obesities 2021, 1, 113-135. [CrossRef]

9. Farajian, P.; Renti, E.; Manios, Y. Obesity indices in relation to cardiovascular disease risk factors among young adult female students. Br. J. Nutr. 2008, 99, 918-924. [CrossRef]

10. Palou, A.; Serra, F.; Bonet, M.; Pico, C. Obesity: Molecular bases of a multifactorial problem. Eur. J. Nutr. 2000, 39, 127-144. [CrossRef] [PubMed]

11. Đorđević-Nikić, M.; Dopsaj, M.; Rakić, S.; Subošić, D.; Prebeg, G.; Macura, M.; Mlađan, M.; Kekić, D. Morphological model of the population of working-age women in Belgrade measured using electrical multichanel bioimpedance model: Pilot study. Phys. Cult. 2013, 67, 103-112.

12. Kyle, U.; Schultz, Y.; Dupertuis, Y.; Pichard, C. Body composition interpretation: Contribution of the fat-free mass index and the body fat mass index. Nutrition 2003, 19, 597-604. [CrossRef]

13. Ling, C.H.; de Craen, A.J.; Slagboom, P.E.; Gunn, D.A.; Stokkel, M.P.; Westendorp, R.G.; Maier, A.B. Accuracy of direct segmental multi-frequency bioimpedance analysis in the assessment of total body and segmental body composition in middle-aged adult population. Clin. Nutrit. 2011, 30, 610-615. [CrossRef] [PubMed] 
14. Dopsaj, M.; Kukić, F.; Đorđević-Nikić, M.; Koropanovski, N.; Radovanović, D.; Miljuš, D.; Subošić, D.; Tomanić, M.; Dopsaj, V. Indicators of absolute and relative changes in skeletal muscle mass during adulthood and ageing. Int. J. Environ. Res. Public Health 2021, 17, 5977. [CrossRef] [PubMed]

15. Dopsaj, M.; Majstorović, N.; Milić, R.; Nesic, G.; Rauter, S.; Zadražnik, M. Multidimensional prediction approach in the assessment of male volleyball players' optimal body composition: The case of two elite European teams. Int. J. Morphol. 2021, 39, 977-983. [CrossRef]

16. Schutz, Y.; Kyle, U.U.G.; Pichard, C. Fat-free mass index and fat mass index percentiles in Caucasians aged 18-98 y. Int. J. Obes. 2002, 26, 953-960. [CrossRef] [PubMed]

17. Dopsaj, M.; Djordjević-Nikić, M.; Khafizova, A.; Eminović, F.; Marković, S.; Yanchik, E.; Dopsaj, V. Structural body composition profile and obesity prevalence at female students of the University of Belgrade measured by multichannel bioimpedance protocol. Hum. Sport Med. 2020, 20, 53-62. [CrossRef]

18. Grujić, V.; Dragnić, N.; Radić, I.; Harhaji, S.; Šušnjević, S. Overweight and obesity among adults in Serbia: Results from the National Health Survey. Eat. Weight Disord. 2010, 15, e34-e42. [CrossRef] [PubMed]

19. Ministry of Health of the Republic of Serbia. Results of the National Health Survey in Serbia, 2013; Institute of Public Health of Serbia: Belgrade, Serbia, 2014. Available online: http:/ / www.batut.org.rs/download/publikacije/IstrazivanjeZdravljaStanovnistvaRS2 013.pdf (accessed on 5 October 2021). (In Serbian)

20. Kukić, F.; Heinrich, K.M.; Koropanovski, N.; Poston, W.S.C.; Čvorović, A.; Dawes, J.J.; Orr, R.; Dopsaj, M. Differences in body composition across Police occupations and moderation effects of leisure time physical activity. Int. J. Environ. Res. Public Health 2020, 17, 6825. [CrossRef]

21. Gába, A.; Přidalová, M. Age-related changes in body composition in a sample of Czech women aged 18-89 years: A cross-sectional study. Eur. J. Nutr. 2014, 53, 167-176. [CrossRef]

22. Sillanpää, E.; Cheng, S.; Häkkinene, K.; Finni, T.; Waleker, S.; Pesola, A.; Ahtiainen, J.; Stenroth, L.; Selänne, H.; Sipilä, S. Body composition in 18-to 88-year-old adults-Comparison of multifrequency bioimpedance and dual-energy X-ray absorptiometry. Obesity 2014, 22, 101-109. [CrossRef]

23. Moreno, L.; Mesana, M.; Fleta, J.; Ruiz, J.; Gonzáles-Gross, M.; Sarría, A.; Marcos, A. Overweight, obesity and body fat composition in Spanis adolescents: The AVENA study. Ann. Nutr. Metab. 2005, 49, 71-78. [CrossRef]

24. Eiben, G.; Dey, D.; Rothenberg, E.; Steen, B.; Björkelund, C.; Bengtsson, C.; Lissner, L. Obesity in 70-year-old Swedes: Secular changes over 30 years. Int. J. Obes. 2005, 29, 810-817. [CrossRef]

25. Wang, Y.; Monteiro, C.; Popkin, B. Trends of obesity and underweight in older children and adolescents in the United States, Brazil, China, and Russia. Am. J. Clin. Nutr. 2002, 75, 971-997. [CrossRef] [PubMed]

26. Kukic, F.; Todorovic, N.; Cvijanovic, N. Effects of a 6-week controled exercise program and semi-controled diet on body fat and skeletal muscle mass in adults. Hum. Sport Med. 2019, 19, 1-7. [CrossRef]

27. Hair, J.F.; Anderson, R.E.; Tatham, R.L.; Black, W.C. Multivariate Data Analysis, 5th ed.; Prentice Hall: Upper Saddle River, NJ, USA, 1998.

28. Jaukendrup, A.; Gleeson, M. Sport Nutrition: An Introduction to Energy Production and Performance, 2nd ed.; Human Kinetics: Champaign, IL, USA, 2009.

29. Nassis, G.P.; Geladas, N.D. Age-related pattern in body composition changes for 18-69 year old women. J. Sport Med. Phys. Fitness 2003, 43, 327-333.

30. Lissner, L.; Sjöberg, A.; Schütze, M.; Lapidus, L.; Hulthén, L.; Björkelund, C. Diet, obesity and obesogenic trends in two generations of Swedish women. Eur. J. Nutr. 2008, 47, 424-431. [CrossRef] [PubMed]

31. Grasgruber, P.; Cacek, J.; Kalina, T.; Sebera, M. The role of nutrition and genetics as key determinants of the positive height trend. Econ. Hum. Biol. 2014, 15, 81-100. [CrossRef] [PubMed] 